\title{
The effects of different beehives on propolis production and quality
}

\author{
Habip KIZILTAS ${ }^{1}$, Cengiz ERKAN ${ }^{1 *}$ (1)
}

\begin{abstract}
The present study was conducted to investigate the effects of wood, styrofoam and plastic beehives on propolis production and phenolic content. In this study, propolis was obtained in three different periods as follows: before, during and after honey production. The yield and quality of the collected raw propolis samples were analyzed. Total phenolic (TP) content, total tannin (TT) content, total antioxidant capacity (FRAP) and phenolic composition were determined as propolis quality parameters. The highest propolis production was determined in wood beehives, followed by styrofoam and plastic beehives in this study. The analysis of temporal propolis production demonstrated that $9.29 \pm 11.37 \mathrm{~g}$ was produced in post-season, $2.88 \pm 4.48 \mathrm{~g}$ was produced in the season, and $1.23 \pm 0.80 \mathrm{~g}$ was produced in pre-season. Duncan and LSD multiple comparison tests, which were conducted to compare the hive groups and the collection periods, demonstrated that the differences were statistically significant $(\mathrm{p}<0.05)$. Furthermore, the highest TP and FRAP values were found in plastic beehives, suggesting that the propolis phenolic content and antioxidant capacity varied based on the hive type and collection period.
\end{abstract}

Keywords: beekeeping; wooden hive; plastic hive; styrofoam hive; propolis; phenolic components.

Practical Application: Effects of hive type on propolis quality.

\section{Introduction}

Propolis is a highly complex resinous substance collected by honeybees from the fresh plant buds or secretions and mixed with beeswax and utilized for different purposes in the hive and includes more than 300 primary compounds (Guo et al., 2015). The human medicine has been interested in this product, used for several purposes, such as paving the hive surfaces, filling the cracks and fractures, polishing the honeycomb cells, narrowing and widening the hive entrance, and coating and isolating possible disease agents, for thousands of years, and it was used in several areas, including mummification and to treat mouth sores (Fokt et al., 2010; Can et al., 2015).

Various alcohol and water-based extracts prepared with propolis are used for various purposes as food additives and supplements. Demand for propolis products, such as skin lotions, beauty creams and balms, massage oils and lotions, shampoos, soaps, lipsticks, gums, toothpaste, sunscreens and lozenges, increases every day. This natural bee product is an indispensable apitherapy agent, which has a wide biological activity spectrum due to antibacterial, antioxidant, antifungal, antiviral, anti-inflammatory and antitumoral properties (Kujumgiev et al., 1999; Amini-Sarteshnizi et al., 2015).

Although the composition of propolis varies based on the plant flora, collection period, hive type, beekeeper performance and hive condition, it usually includes approximately $40-50 \%$ balsam, $20-30 \%$ wax, $5-10 \%$ essential oils, $1-5 \%$ pollen and $5 \%$ various organic compounds (Pietta et al., 2002; Bankova et al., 2019). The vast majority of the balsamic content that includes the active propolis ingredients consist of various polyphenols (phenolic acids, flavonoids, tannins, and their esters), terpenes, volatile organic compounds and various alcohols (Gülçin et al., 2010; Miguel et al., 2010; Baltas et al., 2016).

The global demand for raw propolis products has been increasing, and several studies have been investigating methods to collect higher propolis yields. Previous studies on the factors that affect propolis production are limited, and these studies suggested that the main factors that affect the chemical composition of propolis were bee race, climate, production season and production method (trap structure) (Bankova et al., 2000; Abu Fares et al., 2008; Pujirahayu et al., 2014). An important factor that affects per hive production was the presence of a forest in the vicinity. In a study conducted in Europe, it was reported that annual production, which was around 50-150 g per colony, generally varied within the range of 10-300 g (Abu Fares et al., 2008). Thus, in the present study, the variations in propolis production and quality were investigated based on the collection period and the hive type in the Van lakeshore flora, Turkey. In this study, the propolis yield and quality were investigated using wooden, plastic and styrofoam hives.

\section{Materials and methods}

In this study, where wooden, styrofoam and plastic hives were used in accordance with the Food Codex, Apis mellifera caucasica ( $\mathrm{F}_{1}$ hybrid) honeybee colonies were the bee material. The propolis was produced with plastic traps with a $3 \mathrm{~mm}$ grill.

The 15 colonies used in the propolis production were randomly distributed to wooden, styrofoam and plastic hive groups that included five colonies each. To eliminate the effects of colonial 
strength on propolis production and content, the colonies were equalized as seven bee frames, five of which included brood. Propolis production was conducted in three periods that included pre-season, honey production season and post-season.

To test the phenolic composition and antioxidant capacity of propolis samples, a minimum of 3 grams of propolis sample was used. Therefore, only 34 out of the 45 propolis samples collected were used in analyzes.

\subsection{Extraction}

Three grams of the raw propolis sample was pulverized and transferred to $50 \mathrm{~mL}$ flacons and was shaken at $25^{\circ} \mathrm{C}$ in $98 \%$ ethanol for 48 hours at room temperature. The samples were filtered with a Whatman filter and stored at $-20^{\circ} \mathrm{C}$ until the analysis.

For HPLC analysis, the $\mathrm{pH}$ of the filtrate was adjusted to 1.0 with $\mathrm{HCl}$ and left for two hours, and then, it was extracted with diethyl ether twice, and the upper phase was removed and extracted with ethyl acetate twice, and the upper phase was evaporated until it was dry in a Rotary Evaporator. The remaining part was dissolved in $2 \mathrm{~mL}$ methanol, injected into the device through an HPLC filter (Can et al., 2015).

\subsection{Determination of the phenolic composition with HPLC}

The phenolic content was determined with reverse phase HPLC using a UV lamp. UV analyzes were conducted in two wavelengths (280 and $315 \mathrm{~nm}$ ) with a Hitachi HPLC system equipped with a UV detector with simultaneous response capacity. The analyzes were conducted with Fortis phenyl $(150 \times 4.6 \mathrm{~mm} 5 \mu)$ and application of a gradient program with acetonitrile, water and acetic acid (De Villers et al., 2004). At this stage, the injection volume was set to $25 \mu \mathrm{L}$, the flow rate was set to $1.2 \mathrm{~mL} / \mathrm{m}^{-1}$, and the column temperature was set to 30 degrees in the column furnace (Can et al., 2015).

\subsection{Standards and calibration}

For RP-HPLC-UV analyzes, 14 analytic phenolic standards were used and propylparaben was used as the internal standard. The acidic type stock solutions were prepared in 100\% ethanol and other standards were prepared in 50-50\% ethanol-purified water and $1 \mathrm{mg} / \mathrm{mL}$ concentration. Calibration samples were prepared in five concentrations $(2,5,10,20$, and $30 \mathrm{ppm})$ of 14 standards by diluting the samples with stock solutions and internal standard propylparaben was added to each calibration stock solution to reach a final concentration of $10 \mathrm{ppm}$. The calibration curves were obtained with the ration obtained with the division of the peak areas for each standard concentration by the internal standard peak area. The analyzes were conducted with standard peak differences based on 280-315 nm wavelength.

\subsection{Determination of the Total Phenolic (TP) content}

Total phenolic content analyzes were conducted with the method proposed by Slinkard \& Singleton (1977). Thus, the determination of the total phenolic content is based on the redox reaction where the phenolic compounds reduce the Folin-
Ciocalteu reagent in the alkali medium and are transformed into an oxidized form. The measurement of the absorbance of the blue color formed by the oxidized reagent gives the total phenolic compound content of the analyzed sample. The color intensity of the resulting complex is directly proportional to the phenolic substance concentrations based on the absorbance at $760 \mathrm{~nm}$.

In this study, the gallic acid standard, a phenolic compound, was used to plot the standard graph. Different concentrations of gallic acid in ethanol $(1 ; 0.5 ; 0.25 ; 0.125 ; 0.0625 ; 0.03125 \mathrm{mg} / \mathrm{mL})$ were prepared and the absorbance graph was plotted based on the absorbances in these concentrations, Milligram gallic acid equivalent per 100-gram sample [mg GAE (Gallic Acid Equivalent)/100 g] was noted as phenolic content.

\subsection{Total Tannin content (TT)}

In this study, the total tannin content was calculated based on the method developed by Liu et al. (2009). The method entails a spectrophotometric method to determine total tannin (TT) content based on the formation of a red complex in tannin/strong acid solution. The extract was incubated for $20 \mathrm{~min}$ after the process, and the absorbance was read at $500 \mathrm{~nm}$ against the blind.

\subsection{Determination of ferric (III) reducing antioxidant power (FRAP)}

In this study, Trolox ${ }^{\circledR}$, a standard synthetic antioxidant, was used to plot the standard curve, and a study curve for various concentrations (31.25-62.5-125-250-500-1000 $\mu \mathrm{M}$ ) was plotted.

The method is based on the reduction of Fe (III) ion in the $\mathrm{Fe}$ (III) complex when an antioxidant substance is present. In this method, the Fe (III) ions form the (Fe (III) -TPTZ-2,4,6-tris (2- pyridyl) -S-triazine) complex with the TPTZ ligand, and the blue-colored complex is obtained when it was reduced in the presence of antioxidants, (Fe (II) -TPTZ) provides the maximum absorbance at $593 \mathrm{~nm}$ (Benzie \& Strain, 1999).

In this study, $3 \mathrm{~mL}$ FRAP reagent $[300 \mathrm{mM}$ pH 3.6 acetate buffer: $10 \mathrm{mM}$ TPTZ: $20 \mathrm{mM} \mathrm{FeCl} 3$ (10: 1: 1)] was added to $100 \mu \mathrm{L}$ sample, and absorbances were read at $593 \mathrm{~nm}$ after four minutes. The results were analyzed in comparison with a standard antioxidant, Trolox ${ }^{\oplus}$, and the $\mu$ mol Trolox ${ }^{\oplus}$ equivalent was expressed as an antioxidant power/100 g sample.

\subsection{Statistical analysis}

The propolis samples, produced in three beehive types and during three different periods, were analyzed based on the leastsquares method and Duncan and LSD Multiple Comparison Tests were used to compare the propolis properties. In the analysis, the GLM procedure available in SAS Institute Inc. (2014) software was used.

\section{Results and discussion}

\subsection{Propolis production}

This study was conducted with wooden, Styrofoam, and plastic beehives in three periods, namely pre-season, honey 
production season, and post-season, and propolis production is presented in Table 1 based on hive type and production period.

The findings obtained in this study showed that means propolis production figures for wooden, styrofoam and plastic beehives were $6.72 \pm 11.81,5.14 \pm 5.47$ and $1.34 \pm 1.14$ g, respectively. As seen in Table 1, the highest production figure was obtained in wooden beehives, followed by styrofoam and plastic beehives. Statistical analysis demonstrated that the differences between the groups were significant $(\mathrm{p}<0.05)$.

The analysis of the impacts of the production period on propolis production demonstrated that the mean production figures were $1.23 \pm 0.80 \mathrm{~g}$ in the pre-season, $2.88 \pm 4.48 \mathrm{~g}$ in the season and $9.29 \pm 11.36 \mathrm{~g}$ in the post-season. In this study, the highest propolis production was observed in the postseason and the differences between the periods were statistically significant $(\mathrm{p}<0.05)$.

In this study, propolis was produced in three periods between June 10 and October 10 in wooden, Styrofoam and plastic beehives. Based on the study data, it was determined that the mean propolis production in wooden, styrofoam and plastic hives was $6.72 \mathrm{~g}, 5.14 \mathrm{~g}$ and $1.34 \mathrm{~g}$, respectively. These differences were statistically significant $(\mathrm{p}<0.05)$, and it could be suggested that it hives made with different material and kept in the same ecological conditions were effective in propolis production.

Low yield was another noteworthy finding in this study. Abu Fares et al. (2008) reported that annual production, which is around 50-150 g per colony in European conditions, could vary between 10 and $300 \mathrm{~g}$ in general, and determined the mean yield in the two most productive groups as $15.77 \mathrm{~g}$ and $15.63 \mathrm{~g}$ in their study where they discussed the effects of different modifications and production periods. Sahinler \& Gul (2005) analyzed the effects of Caucasian (A. m. caucasica), Carniolan (A. m. carnica), Italian (A. m. ligustica) and Anatolian (A. m. anatolica) honey bee breeds on propolis production and determined that the respective average yields were $27.34 \mathrm{~g}, 26.93 \mathrm{~g}, 26.12 \mathrm{~g}$ and 39.67 g, respectively. Similarly, Nuru et al. Nuru et al. (2002) discussed the propolis production in framed hives and local basket hives and reported that the mean production by $A . m$. bandasii bees in framed hives was $24.2 \pm 22.5 \mathrm{~g}$ and the same figure was $12.7 \pm 8.6 \mathrm{~g}$ in basket hives for 19 months.

It was suggested that the main reason for the low mean production figures in the present study when compared to other studies was the shorter production period. Also, in the present study that started immediately before the honey production season, colonies were forced to produce propolis while conducting activities, such as honeycomb production and brooding. Furthermore, given that the field study was terminated before mid-autumn when propolis production peaks, this was considered as another factor that led to low production.

The production period affects propolis production, and the highest yield is obtained in late autumn and early winter (Jager et al., 2002; Karlıdag \& Genc, 2007; Abu Fares et al., 2008). In the present study, the mean propolis production during three periods, namely pre-season, honey production season and postseason, were measured as $1.23 \mathrm{~g}, 2.88 \mathrm{~g}$ and $9.29 \mathrm{~g}$, respectively, and the differences between the periods were statistically significant. This finding was consistent with previous studies.

\subsection{Phenolic contents and profiles}

In this study where 14 phenolic standards were used, validation values that included the upper and lower determination limits and repeatability sensitivity for each phenolic compound in reverse phase UV-HPLC are summarized in Table 2.

In Table 2, LOD depicts the lower limit of determination, LOQ indicates the upper limit of determination, RSD\% denotes the areas, and $\mathrm{R}^{2}$ indicates repeatability (Cakir et al., 2018).

The HPLC values for mixtures prepared with propolis obtained from three types of hives are presented as $\mu \mathrm{g} / \mathrm{g}$ in Table 3.

The findings obtained in this study showed that 12 out of the 14 standard phenolics (gallic acid, protocatechuic acid, p-OH benzoic acid, vanillic acid, caffeic acid, syringic acid, syringic acid, p-coumaric acid, ferulic acid, rutin, daidzein, t-cinnamic acid and luteolin) were within standard ranges, while catechin and epicatechin were below the determination value in all three hive groups.

Propolis is a high biological activity product due to the polyphenol content and especially due to the presence of active polyphenols, such as rutin, caffeic acid, daidzein, quercetin and caffeic acid phenyl ester (CAPE). The presence and content of these molecules vary based on the regional flora.

In this study, in the phenolic profile analysis conducted with 14 phenolic standards, it was determined that the propolis obtained from all hives exhibited similar phenolic composition except catechin and epicatechin. While the caffeic acid and rutin content were higher in the plastic hive, ferulic acid was observed to be higher in the wooden hive group. It is not possible to draw a meaningful conclusion based on the data obtained on phenolic component types. However, it was determined that there were significant differences between the hives based on total phenolic

Table 1. Propolis production (g/hive).

\begin{tabular}{|c|c|c|c|c|c|c|c|c|}
\hline \multirow{3}{*}{ Period } & \multicolumn{6}{|c|}{ Beehive type } & \multirow{2}{*}{\multicolumn{2}{|c|}{ Total $^{*}$}} \\
\hline & \multicolumn{2}{|c|}{ Wooden } & \multicolumn{2}{|c|}{ Styrofoam } & \multicolumn{2}{|c|}{ Plastic } & & \\
\hline & Number & Mean \pm S.E. & Number & Mean \pm S.E. & Number & Mean \pm S.E. & Number & Mean \pm S.E. \\
\hline Pre-season & 5 & $1.70 \pm 1.20$ & 5 & $0.80 \pm 0.27$ & 5 & $1.20 \pm 0.45$ & 15 & $1.23 \pm 0.80^{\mathrm{A}}$ \\
\hline Season & 5 & $0.86 \pm 0.77$ & 5 & $6.02 \pm 6.26$ & 3 & $1.03 \pm 0.87$ & 13 & $2.88 \pm 4.48^{\mathrm{A}}$ \\
\hline Post-season & 5 & $17.60 \pm 16.23$ & 5 & $8.60 \pm 5.08$ & 5 & $1.66 \pm 1.75$ & 15 & $9.29 \pm 11.36^{\mathrm{B}}$ \\
\hline $\operatorname{Total}^{*}$ & 15 & $6.72 \pm 11.81^{\mathrm{A}}$ & 15 & $5.14 \pm 5.47^{\mathrm{AB}}$ & 13 & $1.34 \pm 1.14^{\mathrm{B}}$ & & \\
\hline
\end{tabular}

*The differences between seasonal mean figures indicated by different letters were statistically significant $(\mathrm{p}<0.05)$. S.E. $=$ Standard Error. 
Table 2. RP-HPLC-UV phenolic compound validation values.

\begin{tabular}{|c|c|c|c|c|c|}
\hline Compound & $R^{2}$ & RSD (\%) & RSD (\%) & $\mathrm{LOD}(\mathrm{mg} / \mathrm{L})$ & $\mathrm{LOQ}(\mathrm{mg} / \mathrm{L})$ \\
\hline Gallic Acid & 0.999 & 0.210 & 1.941 & 0.022 & 0.067 \\
\hline Protocatechuic Acid & 0.999 & 0.871 & 1.920 & 0.042 & 0.128 \\
\hline p-OH Benzoic Acid & 0.998 & 0.351 & 3.055 & 0.036 & 0.109 \\
\hline Catechin & 0.997 & 0.492 & 4.279 & 0.040 & 0.121 \\
\hline Vanillic Acid & 1.000 & 0.828 & 2.066 & 0.025 & 0.075 \\
\hline Caffeic Acid & 0.998 & 0.179 & 4.039 & 0.062 & 0.187 \\
\hline Syringic Acid & 1.000 & 0.550 & 0.848 & 0.009 & 0.027 \\
\hline Epicatechin & 0.999 & 0.429 & 3.819 & 0.030 & 0.090 \\
\hline p-Coumaric Acid & 0.999 & 0.204 & 1.562 & 0.010 & 0.030 \\
\hline Ferulic Acid & 0.999 & 0.222 & 1.301 & 0.011 & 0.033 \\
\hline Rutin & 1.000 & 0.234 & 3.139 & 0.041 & 0.123 \\
\hline Daidzein & 0.998 & 0.174 & 1.545 & 0.018 & 0.054 \\
\hline$t$-Cinnamic Acid & 1.000 & 0.262 & 1.071 & 0.014 & 0.042 \\
\hline Luteolin & 0.994 & 0.229 & 5.833 & 0.043 & 0.130 \\
\hline
\end{tabular}

$R^{2}=$ Coefficient of Determination. RSD $(\%)=$ Relative Standard Deviation. LOD = Limit of Detection. LOQ = Limit of Quantification.

Table 3. Propolis phenolic acid compositions (mg/100 g).

\begin{tabular}{|c|c|c|c|c|}
\hline & Phenolic standards & Wooden & Styrofoam & Plastic \\
\hline \multirow{10}{*}{ Phenolic acid } & Gallic acid & 2.50 & 1.58 & 1.80 \\
\hline & Protocatechuic acid & 1.25 & 0.18 & 1.52 \\
\hline & $p$-OH Benzoic acid & 3.40 & 3.07 & 2.36 \\
\hline & Catechin & ND & ND & ND \\
\hline & Vanillic acid & 17.50 & 16.19 & 11.80 \\
\hline & Caffeic acid & 18.01 & 11.22 & 61.90 \\
\hline & Syringic acid & 3.50 & 6.42 & 5.75 \\
\hline & p-Coumaric acid & 20.8 & 6.58 & 24.10 \\
\hline & Ferulic acid & 90.56 & 8.10 & 23.05 \\
\hline & $t$-Cinnamic acid & 5.45 & 6.10 & 14.02 \\
\hline \multirow{4}{*}{ Flavonoid } & Epicatechin & ND & ND & ND \\
\hline & Daidzein & 56.50 & 35.40 & 17.67 \\
\hline & Rutin & 34.7 & 22.54 & 169.50 \\
\hline & Luteolin & 3.60 & 1.47 & 2.39 \\
\hline
\end{tabular}

ND: Not detected.

content and total tannin content. Propolis produced in plastic beehives exhibited higher phenolic content, followed by wooden and Styrofoam beehives. It was determined that the highest total tannin and total antioxidant capacity were obtained in plastic beehives, followed by wood and Styrofoam beehives, and the correlations between these findings were positive.

In this study, TP content of propolis collected from wooden, styrofoam and plastic beehives are presented in Table 4 and it was observed that the mean figures varied between 133.4 and $555.2 \mathrm{mg} / \mathrm{g}$. While the lowest TP was calculated in styrofoam with $203.4 \pm 154.0 \mathrm{mg} / \mathrm{g}$ among the beehive groups, the plastic beehives produced the highest TP with $413.3 \pm 212.9 \mathrm{mg} / \mathrm{g}$. It was determined that the differences between the hive groups were statistically significant $(\mathrm{p}<0.05)$.

Based on the harvest periods, it was found that the pre-season harvest phenolic content $(483.1 \pm 194.8 \mathrm{mg} / \mathrm{g})$ was higher when compared to the season $(195.8 \pm 121.6 \mathrm{mg} / \mathrm{g})$ and post-season $(166.9 \pm 48.1 \mathrm{mg} / \mathrm{g})$. These differences were also statistically significant $(\mathrm{p}<0.05)$.
Total polyphenolic content is an important parameter in the determination of the phenolic content in natural products and high phenolic content indicates high biological activity (Kolayli et al., 2016; Can et al., 2015; Kaygusuz et al., 2016). Another study reported that bee breeds affected the quality of propolis and other bee products (Saral et al., 2019). The present study findings demonstrated that the total phenolic content was at the highest level in pre-season, gradually decreased over time and reached the lowest level in the post-season. In this study, it was determined that the above-mentioned trend was similar in all three hive types, and the comparison of the hive groups demonstrated significant differences between the groups. The propolis produced in plastic hives led to higher phenolic content, followed by wooden and styrofoam hives. Given that there was a positive correlation between the total phenolic content and total antioxidant capacity increases the significance of the finding that the propolis produced in plastic beehives exhibited higher phenolic content among the hive groups under the same ecological conditions. 
As seen in Table 5, total tannin (TT) content was similar in the wooden and styrofoam hives $(5430.9 \pm 2168.3$ and $5383.1 \pm 719.7 \mathrm{mg} / 100 \mathrm{~g}$, respectively) and total tannin content was lower in the plastic hives $(4183.4 \pm 1550.7 \mathrm{mg} / 100 \mathrm{~g}$.) when compared to the other two groups. Based on the production periods, it was found that the post-season propolis TT content $(5669.9 \pm 1441.4 \mathrm{mg} / 100 \mathrm{~g})$ was higher when compared to those produced in the pre-season $(4379.8 \pm 1555.9 \mathrm{mg} / 100 \mathrm{~g})$ and in the season $(4572.7 \pm 1713.0 \mathrm{mg} / 100 \mathrm{~g})$. In this study, it was determined that the differences between the mean figures based on hive type and the period were statistically significant $(\mathrm{p}<0.05)$.

Tannin, a polyphenol that penetrates propolis from the tree bark and leaves, is a compound that determines the color of the propolis, and tannin content is higher amounts in dark-colored propolis. In this study, the highest tannin content was determined in wooded and Styrofoam hive groups, and the figures for both groups were similar, while propolis samples obtained from plastic hives were lower. It was suggested that propolis collection tendency, which is likely to vary based on the in-hive requirements, was effective on the above-mentioned difference. Furthermore, it is possible to associate the increasing tannin content based on the progress of the season with vegetation because, during the post-honey production season, propolis collection activity changes from lower herbaceous sources to higher woody sources, increasing the tannin content.
FRAP is the most commonly used method to determine the Total Antioxidant Capacity (TAC) of propolis, which is a strong antioxidant source. In this method, based on the technique of reducing the ferrous (III) complex, a high FRAP value is directly associated with the antioxidant capacity.

In the present study conducted on propolis collected from different types of beehives, the findings showed that the highest FRAP value was obtained with plastic hives $(432.6 \pm 236.8 \mu \mathrm{mol}$ Trolox/100 g), while wooden $(374.3 \pm 264.4 \mu$ molTrolox/100 g) and Styrofoam ( $257.3 \pm 187.3 \mu \mathrm{mol}$ Trolox/100 g) hives revealed similar findings. As seen in Table 6, the high FRAP value was high in the pre-season $(540.0 \pm 267.1 \mu \mathrm{mol}$ Troloks $/ 100 \mathrm{~g})$ and decreased through the season $(346.3 \pm 176.1 \mu$ molTrolox/100 g), and reached the lowest value in the post-season $(177.6 \pm 43.7 \mu \mathrm{mol}$ Trolox $/ 100 \mathrm{~g}$ ). In this study, it was also revealed that the differences based on both hive type and seasons were significant $(\mathrm{p}<0.05)$, and there was a positive correlation $\left(\mathrm{R}^{2}=0.70\right)$ between total phenolic content and total antioxidant capacity.

In general, all types of factors that prevent or reduce oxidation are called antioxidants. According to the FRAP method used to analyze the Total Antioxidant Capacity (TAC), high FRAP values reflect high antioxidant capacity. As seen in Table 6, the highest FRAP finding obtained in the pre-season decreased with time and reached the lowest level during the post-honey

Table 4. Total phenolic (TP) substance content (mg GAE/g).

\begin{tabular}{|c|c|c|c|c|c|c|c|c|}
\hline \multirow{3}{*}{ Period } & \multicolumn{6}{|c|}{ Beehive type } & \multirow{2}{*}{\multicolumn{2}{|c|}{ Total $^{*}$}} \\
\hline & \multicolumn{2}{|c|}{ Wooden } & \multicolumn{2}{|c|}{ Styrofoam } & \multicolumn{2}{|c|}{ Plastic } & & \\
\hline & Number & Mean \pm S.E. & Number & Mean \pm S.E. & Number & Mean \pm S.E. & Number & Mean \pm S.E. \\
\hline Pre-season & 12 & $455.0 \pm 182.0$ & 9 & $400.5 \pm 204.0$ & 15 & $555.2 \pm 185.6$ & 36 & $483.1 \pm 194.8^{\mathrm{A}}$ \\
\hline Season & 9 & $177.6 \pm 72.3$ & 12 & $133.4 \pm 43.6$ & 6 & $347.7 \pm 163.5$ & 27 & $195.8 \pm 121.6^{\mathrm{B}}$ \\
\hline Post-season & 15 & $160.5 \pm 20.7$ & 15 & $141.2 \pm 25.8$ & 9 & $220.5 \pm 67.4$ & 39 & $166.9 \pm 48.1^{\mathrm{C}}$ \\
\hline Total $^{*}$ & 36 & $263.0 \pm 175.5^{\mathrm{A}}$ & 36 & $203.4 \pm 154.0^{\mathrm{B}}$ & 30 & $413.3 \pm 212.9^{C}$ & & \\
\hline
\end{tabular}

*The differences between beehive type and seasonal mean figures indicated by different letters were statistically significant $(\mathrm{p}<0.05)$. S.E. $=$ Standard Error.

Table 5. Total tannin (TT) content (mg Catechin/100 g).

\begin{tabular}{|c|c|c|c|c|c|c|c|c|}
\hline \multirow{3}{*}{ Period } & \multicolumn{6}{|c|}{ Beehive type } & \multirow{2}{*}{\multicolumn{2}{|c|}{ Total $^{*}$}} \\
\hline & \multicolumn{2}{|r|}{ Wooden } & \multicolumn{2}{|c|}{ Styrofoam } & \multicolumn{2}{|r|}{ Plastic } & & \\
\hline & Number & Mean \pm S.E. & Number & Mean \pm S.E. & Number & Mean \pm S.E. & Number & Mean \pm S.E. \\
\hline Pre-season & 3 & $6352.2 \pm 35.7$ & 3 & $4678.4 \pm 14.8$ & 6 & $3244.2 \pm 1178.9$ & 12 & $4379.8 \pm 1555.9^{\mathrm{A}}$ \\
\hline Season & 9 & $3738.9 \pm 1617.4$ & 12 & $5760.7 \pm 862.2$ & 3 & $2322.7 \pm 26.2$ & 24 & $4572.7 \pm 1713.0^{\mathrm{A}}$ \\
\hline Post-season & 15 & $6261.9 \pm 2115.3$ & 15 & $5221.9 \pm 482.0$ & 9 & $5429.7 \pm 730.5$ & 39 & $5669.9 \pm 1441.4^{\mathrm{B}}$ \\
\hline Total $^{*}$ & 27 & $5430.9 \pm 2168.3^{\mathrm{A}}$ & 30 & $5383.1 \pm 719.7^{\mathrm{A}}$ & 18 & $4183.4 \pm 1550.7^{\mathrm{B}}$ & & \\
\hline
\end{tabular}

${ }^{*}$ The differences between beehive type and seasonal mean figures indicated by different letters were statistically significant $(\mathrm{p}<0.05)$. S.E. $=$ Standard Error.

Table 6. FRAP findings ( $\mu$ mol Trolox/100 g).

\begin{tabular}{|c|c|c|c|c|c|c|c|c|}
\hline \multirow{3}{*}{ Period } & \multicolumn{6}{|c|}{ Beehive type } & \multirow{2}{*}{\multicolumn{2}{|c|}{ Total $^{*}$}} \\
\hline & \multicolumn{2}{|c|}{ Wooden } & \multicolumn{2}{|c|}{ Styrofoam } & \multicolumn{2}{|c|}{ Plastic } & & \\
\hline & Number & Mean \pm S.E. & Number & Mean \pm S.E. & Number & Mean \pm S.E. & Number & Mean \pm S.E. \\
\hline Pre-season & 12 & $587.6 \pm 346.2$ & 9 & $487.9 \pm 256.7$ & 15 & $533.3 \pm 206.8$ & 36 & $540.0 \pm 267.1^{\mathrm{A}}$ \\
\hline Season & 9 & $376.0 \pm 117.7$ & 12 & $197.9 \pm 54.9$ & 6 & $598.5 \pm 41.1$ & 27 & $346.3 \pm 176.1^{\mathrm{B}}$ \\
\hline Post-season & 15 & $202.7 \pm 45.9$ & 15 & $166.4 \pm 40.3$ & 9 & $154.2 \pm 22.9$ & 39 & $177.5 \pm 43.7^{\mathrm{C}}$ \\
\hline Total $^{*}$ & 36 & $374.3 \pm 264.4^{\mathrm{A}}$ & 36 & $257.3 \pm 187.3^{\mathrm{B}}$ & 30 & $432.6 \pm 236.8^{\mathrm{A}}$ & & \\
\hline
\end{tabular}

*The differences between beehive type and seasonal mean figures indicated by different letters are statistically significant $(\mathrm{p}<0.05)$. S.E. $=$ Standard Error. 
production season. In a study by Chen et al. (2008) conducted on the composition of the propolis collected at different times, the findings showed that the phenolic content of the propolis produced in spring was higher, and in a study by Calegari et al. (2017) that aimed to investigate the effects of season and feeding on antioxidant activity and phenolic profile of propolis, the highest phenolic content and antioxidant activity were determined in spring (March and April) production when compared to summer (May and June) production, and the above-mentioned findings were consistent with the findings that were obtained in the present study that there was a positive correlation between the total phenolic content and total antioxidant capacity.

\section{Conclusion}

The results of the present study conducted to investigate the effects of wooden, styrofoam and plastic beehives on propolis yield and phenolic content showed that the propolis yield, phenolic content, and antioxidant capacity varied based on beehive type and harvest season. In addition, after the honey harvest was completed, the yield and quality of propolis increased as honeybees began to accumulate propolis in the hive.

\section{Acknowledgements}

This research was carried out by the Scientific Research Projects Coordination Unit of Van Yuzuncu Yil University within the scope of the project numbered 2015-FBE-YL 186. The authors would like to express their appreciation to the Scientific Research Projects Coordination Unit of Van Yuzuncu Yil University. This study was presented as an oral presentation in " ${ }^{\text {th }}$ International Muğla Beekeeping \& Pine Honey Congress" and was published as abstract only.

\section{References}

Abu Fares, R. J., Nazer, I. K., Darwish, R. M., \& Abu Zarqa, M. (2008). Honey bee hive modification for propolis collection. Jordan Journal of Agricultural Sciences, 4(2), 138-147. Retrieved from https://search. emarefa.net/detail/BIM-275124

Amini-Sarteshnizi, N., Mobini-Dehkordi, M., Khosravi-Farsani, S., \& Teimori, H. (2015). Anticancer activity of ethanolic extract of propolis on AGS cell line. Journal of Herbmed Pharmacology, 4, 29-34. Retrieved from http://herbmedpharmacol.com/Article/JHP_20150527174303

Baltas, N., Karaoglu, S. A., Tarakci, C., \& Kolayli, S. (2016). Effect of propolis in gastric disorders: inhibition studies on the growth of helicobacter pylori and production of Its urease. Journal of Enzyme Inhibition and Medicinal Chemistry, 31(Suppl. 2), 46-50. http://dx.doi. org/10.1080/14756366.2016.1186023. PMid:27233102.

Bankova, V. S., Castro, S. L., \& Marcucci, M. C. (2000). Propolis: recent advances in chemistry and plant origin. Apidologie, 31(1), 3-15. http://dx.doi.org/10.1051/apido:2000102.

Bankova, V., Bertelli, D., Borba, R., Conti, B. J., Cunha, I. B. S.., Danert, C., Eberlin, M. N., I Falcão, S., Isla, M. I., Moreno, M. I. N., Papotti, G., Popova, M., Santiago, K. B., Salas, A., Sawaya, A. C. H. F., Schwab, N. V., Sforcin, J. M., Simone-Finstrom, M., Spivak, M., Trusheva, B., Vilas-Boas, M., Wilson, M., \& Zampini, C. (2019). Standard methods for Apis mellifera propolis research. Journal of Apicultural Research, 58(2), 1-49. http://dx.doi.org/10.1080/00218839.2016.1222661.
Benzie, I. F., \& Strain, J. J. (1999). Ferric reducing antioxidant power assay: direct measure of total antioxidant activity of biological fluids and modified version for simultaneous measurement of total antioxidant power and ascorbic acid concentration. Methods in Enzymology, 299, 15-27. http://dx.doi.org/10.1016/S0076-6879(99)99005-5. PMid:9916193.

Cakir, H. E., Sirin, Y., Kolayli, S., \& Can, Z. (2018). Validation methods for phenolic components with RP-HPLC-UV in various bee products. Apiterapi ve Doğa Dergisi, 1(1), 13-19. Retrieved from https:// dergipark.org.tr/tr/pub/jan/issue/36344/374912

Calegari, M. A., Prasniewski, A., Silva, C. D., Sado, R. Y., Maia, F., Tonial, L., \& Oldoni, T. L. (2017). Propolis from Southwest of Parana produced by selected bees: Influence of seasonality and food supplementation on antioxidant activity and phenolic profile. Anais da Academia Brasileira de Ciências, 89(1), 45-55. http://dx.doi. org/10.1590/0001-3765201620160499. PMid:28177054.

Can, Z., Yildiz, O., Sahin, H., Akyuz Turumtay, E., Silici, S., \& Kolayli, S. (2015). An investigation of Turkish honeys: their physico-chemical properties, antioxidant capacities and phenolic profiles. Food Chemistry, 180, 133-141. http://dx.doi.org/10.1016/j.foodchem.2015.02.024. PMid:25766810.

Chen, Y. W., Wu, S. W., Ho, K. K., Lin, S. B., Huang, C. Y., \& Chen, C. N. (2008). Characterisation of Taiwanese propolis collected from different locations and seasons. Journal of the Science of Food and Agriculture, 88(3), 412-419. http://dx.doi.org/10.1002/jsfa.3101.

De Villers, A., Lynen, F., Crouch, A., \& Sandra, P. (2004). Development of a solid-phase extraction procedure for the simultaneous determination of polyphenols. organic acids and sugars in wine. Chromatographia, 59(7-8), 403-409. http://dx.doi.org/10.1365/s10337-004-0204-1.

Fokt, H., Pereira, A., Ferreira, A. M., Cunha, A., \& Aguiar, C. (2010). How do bees prevent hive infections? The antimicrobial properties of propolis. In A. Méndez-Vilas (Ed.), Current research, technology and education: topics in applied microbiology and microbial biotechnology (pp. 481-493). Badajoz, Spain: Formatex Research Center. Retrieved from https://pdfs.semanticscholar.org/0c57/ d5da3686818974693a1626c062a61fb8749d.pdf

Gülçin, I., Bursal, E., Sehitoglu, M. H., Bilsel, M., \& Goren, A. C. (2010). Polyphenol contents and antioxidant activity of lyophilized aqueous extract of propolis from Erzurum, Turkey. Food and Chemical Toxicology, 48(8-9), 2227-2238. http://dx.doi.org/10.1016/j. fct.2010.05.053. PMid:20685228.

Guo, S., Fu, S., Shen, Z., Zhang, Z., \& Xu, Q. (2015). Chemical composition, biological activity and application in animal science of propolis: a review. In Proceedings of the International Seminar on Poultry Diseases. Pakistan: Department of Pathology, University of Agriculture. Retrieved from https://scholar.google.com/scholar_lookup?journal=Advances+in+Biomedical+Engineering\&title =Chemical+composition,+biological+activity+and+application + in + animal+science + of + propolis- $A+$ review\&author $=S+$ Guo\&aut hor $=\mathrm{S}+$ Fu\&author $=\mathrm{Z}+$ Shen \&author $=\mathrm{Z}+\mathrm{Zhang}$ \&author $=\mathrm{Q}+\mathrm{Xu}$ \& publication_year $=2011$ \&pages $=98-101 \&$

Jager, A. J., Taylor, G. J., Greeff, P., \& Lishman, A. W. (2002). The effect of commercial propolis production on hive profitability. Apiacta, 3, 1-4. Retrieved from https://pdfs.semanticscholar.org/c8d2/8f57437d12161b9 02cc60ea74850af633f51.pdf?_ga=2.259762954.1609461392.1588277664745599301.1588277664

Karlıdag, S., \& Genc, F. (2007). Resin yield of propolis samples produced by different honeybee races and methods. Uludag Bee Journal, 7, 5258. Retrieved from http://static.dergipark.org.tr/article-download/ imported/5000034669/5000034133.pdf? 
Kaygusuz, H., Tezcan, F., Bedia Erim, F., Yildiz, O., Sahin, H., Can, Z., \& Kolayli, S. (2016). Characterization of Anatolian honeys based on minerals, bioactive components and principal component analysis. Lebensmittel-Wissenschaft + Technologie, 68, 273-279. http://dx.doi. org/10.1016/j.lwt.2015.12.005.

Kolayli, S., Can, Z., Yildiz, O., Sahin, H., \& Karaoglu, S. A. (2016). A comparative study of the antihyaluronidase, antiurease, antioxidant, antimicrobial and physicochemical properties of different unifloral degrees of chestnut (Castanea sativa Mill.) honeys. Journal of Enzyme Inhibition and Medicinal Chemistry, 31(Suppl. 3), 96-104. http:// dx.doi.org/10.1080/14756366.2016.1209494. PMid:27440492.

Kujumgiev, A., Tsvetkova, I., Serkedjieva, Y., Bankova, V., Christov, R., \& Popov, S. (1999). Antibacterial, antifungal and antiviral activity of propolis of Different geographic origin. Journal of Ethnopharmacology, 64(3), 235-240. http://dx.doi.org/10.1016/S0378-8741(98)00131-7. PMid:10363838.

Liu, L., Sun, Y., Laura, T., Liang, X., Ye, H., \& Zeng, X. (2009). Determination of polyphenolic content and antioxidant activity of kudingcha made from Ilex kudingcha C.J. Tseng. Food Chemistry, 112(1), 35-41. http://dx.doi.org/10.1016/j.foodchem.2008.05.038.

Miguel, M. G., Nunes, S., Dandlen, S. A., Cavaco, A. M., \& Antunes, M. D. (2010). Phenols and antioxidant activity of hydro-alcoholic extracts of propolis from Algarve, South of Portugal. Food and Chemical Toxicology, 48(12), 3418-3423. http://dx.doi.org/10.1016/j. fct.2010.09.014. PMid:20849908.
Nuru, A., Hepburn, H. R., \& Radloff, S. E. (2002). Induction of propolis production by Apis mellifera bandasii in traditional basket and Langstroth movable-frame hives in Ethiopia. Journal of Apicultural Research, 41(3-4), 101-106. http://dx.doi.org/10.1080/00218839.2002.11101076.

Pietta, P. G., Gardana, C., \& Pietta, A. M. (2002). Analytical methods for quality control of propolis. Fitoterapia, 73(Suppl. 1), S7-S20. http://dx.doi.org/10.1016/S0367-326X(02)00186-7. PMid:12495705.

Pujirahayu, N., Ritonga, H., \& Uslinawaty, Z. (2014). Properties and flavonoids content in propolis of some extraction method of raw propolis. International Journal of Pharmacy and Pharmaceutical Sciences, 6(6), 338-340. Retrieved from https://pdfs.semanticscholar. org/02c1/30d1f4a47477a7eb139cfa75db9a0bac3696.pdf

Sahinler, N., \& Gul, A. (2005). The effects of propolis production methods and honeybee genotypes on propolis yield. Pakistan Journal of Biological Sciences, 8(9), 1212-1214. http://dx.doi.org/10.3923/ pjbs.2005.1212.1214.

Saral, O., Kilicarslan, M., Sahin, H., Yildiz, O., \& Dincer, B. (2019). Evaluation of antioxidant activity of bee products of different bee races in Turkey. Turkish Journal of Veterinary and Animal Sciences, 43(4), 441-447. http://dx.doi.org/10.3906/vet-1901-3.

SAS Institute Inc. (2014). SAS/STAT. Cary.

Slinkard, K., \& Singleton, V. L. (1977). Total phenol analysis: automation and comparison with manual methods. American Journal of Enology and Viticulture, 28, 49-55. Retrieved from https://www.ajevonline. org/content/28/1/49 